\title{
ANALISIS RASIO KEUANGAN \\ PADA PT. PEGADAIAN (PERSERO) \\ CABANG ULAK KARANG
}

\author{
Yelmi Pramita, Afriyeni \\ Akademi Keuangan dan Perbankan Padang \\ Afriyeni.yen@gmail.com
}

\begin{abstract}
ABSTRAK
Perkembangan posisi keuangan mempunyai arti yang sangat penting bagi perusahaan. Alat yang digunakan untuk mengetahui kondisi keuangan perusahaan dapat berwujud laporan keuangan. PT Pegadaian (Persero) sebagai salah satu Badan Usaha Milik Negara juga perlu diketahui kondisi keuangannya untuk mengetahui kinerja keuangan perusahaan. Adapun salah satu alat yang dapat digunakan dalam menilai kinerja keuangan adalah analisis terhadap rasio-rasio keuangan. Rasio tersebut adalah rasio likuiditas, solvabilitas, aktivitas, dan profitabilitas. Tujuan penelitian ini adalah : 1) untuk mengetahui dan menganalisis rasio keuangan PT. Pegadaian (Persero) Cabang Ulak Karang berdasarkan rasio likuiditas, 2) untuk mengetahui dan menganalisis rasio keuangan PT. Pegadaian (Persero) Cabang Ulak Karang berdasarkan rasio solvabilitas, 3) untuk mengetahui dan menganalisis rasio keuangan PT. Pegadaian (Persero) Cabang Ulak Karang berdasarkaan rasio profitabilitas. Data penelitian ini bersumber dari Laporan Keuangan PT Pegadaian (Persero) Cabang Ulak Karang pada tahun 2014-2016. Metode yang digunakan dalam penelitian ini adalah analisa data kualitatif dan kuantitatif. Hasil penelitian ini menunjukkan bahwa kinerja perusahaan diukur menggunakan rasio likuiditas, rasio solvabilitas, dan rasio profitabilitas.
\end{abstract}

Kata Kunci: Rasio Keuangan

\section{LATAR BELAKANG}

Perkembangan suatu perusahaan dapat dilihat dari laporan keuangannya. Laporan keuangan adalah laporan yang menyediakan informasi tentang posisi keuangan pada saat tertentu yang ditujukan bagi pengguna laporan didalam maupun diluar perusahaan untuk menilai dan mengambil keputusan yang berhubungan dengan perusahaan. Laporan keuangan menurut Harahap (2005:201) adalah "Laporan keuangan merupakan output dan hasil akhir dari proses akuntansi. Laporan keuangan inilah yang menjadi bahan informasi bagi para pemakainya sebagai sumber informasi, laporan keuangan juga sebagai pertanggungjawaban atau accountability. Sekaligus menggambarkan indikator kesuksesan dalam mencapai tujuannya". 
Laporan keuangan terdiri dari neraca, laporan laba rugi serta laporanlaporan keuangan lainnya. Neraca menggambarkan seberapa besar harta, kekayaan, hutang maupun modal perusahaan pada saat tertentu. Sedangkan laporan laba rugi menggambarkan hasil operasi perusahaan pada periode tertentu.

Adapun salah satu alat yang dapat digunakan dalam menilai kinerja keuangan adalah analisis terhadap rasio-rasio keuangan. Penggunaan analisis rasio keuangan dapat memberikan informasi bagi manajemen tentang tingkat likuiditas, aktivitas, solvabilitas, dan profitabilitas perusahaan. Hasil yang telah dianalisis tersebut dapat juga digunakan untuk mengetahui penyimpangan dan kelemahan yang terdapat dalam perusahaan serta dapat digunakan untuk menjaga atau memperbaiki kondisi keuangan perusahaan sehingga kerugian yang mungkin terjadi dapat dihindari. Selain itu laporan keuangan juga menjadi hal yang penting bagi manajemen karena dapat digunakan sebagai pertanggungjawaban kepada pemilik perusahaan atas kepercayaan yang telah diberikan.

PT. Pegadaian (Persero) merupakan badan usaha yang bergerak dibidang pelayanan jasa pegadaian kepada masyarakat dengan cara khusus yaitu hukum gadai. Dalam menjalankan aktivitasnya PT. Pegadaian menggunakan dana yang cukup besar dimana dalam pengelolaannya diperlukan data yang lengkap sebagai dasar pengambilan keputusan yang baik terutama untuk mengetahui kemampuan perusahaan dalam memperoleh keuntungan selama melakukan kegiatan operasinya.

Laporan keuangan belumlah berguna bila belum dianalisa, dalam rangka mendapatkan informasi yang dibutuhkan oleh pihak-pihak yang berkepentingan. Dengan pengukuran menggunakan rasio keuangan maka dapat mengetahui kinerja perusahaan serta dapat digunakan untuk menarik investor dan kreditur. Selain itu juga untuk menilai kondisi keuangan dan hasil usaha perusahaan baik dalam jangka pendek maupun jangka panjang. Selain berguna dalam proses pengambilan keputusan, informasi yang ada dalam laporan keuangan juga dibutuhkan sebagai pertanggungjawaban manajemen. Hal ini berarti semua pihak-pihak yang berkepentingan terhadap perusahaan dapat mengadakan pengujian terhadap usaha-usaha yang dilaksanakan. Pada Tabel 1 disajikan beberapa data keuangan dari PT. Pegadaian (Persero) Cabang Ulak Karang selama tahun 2014 sampai dengan tahun 2016.

Tabel 1

Data Keuangan PT. Pegadaian (Persero) Cabang Ulak Karang Periode Tahun 2014-2016

\begin{tabular}{|l|r|r|r|}
\hline \multicolumn{1}{|c|}{ Ket. } & \multicolumn{1}{l|}{$\begin{array}{l}\text { Tahun 2014 } \\
(\mathbf{R p})\end{array}$} & \multicolumn{1}{l|}{$\begin{array}{l}\text { Tahun 2015 } \\
(\mathbf{R p})\end{array}$} & \multicolumn{1}{l|}{$\begin{array}{l}\text { Tahun 2016 } \\
(\mathbf{R p})\end{array}$} \\
\hline Total Aktiva & 14.328 .149 .489 & 15.148 .374 .097 & 17.653 .807 .692 \\
\hline Pendapatan & 2.648 .492 .739 & 3.420 .167 .918 & 3.434 .318 .246 \\
\hline Beban & 3.736 .380 .741 & 4.171 .587 .559 & 3.213 .893 .861 \\
\hline
\end{tabular}

Sumber : PT. Pegadaian (Persero) Cabang Ulak Karang \& data diolah 
Berdasarkan tabel 1 diatas kita dapat mengetahui bahwa total aktiva dan pendapatan dari tahun 2014 sampai dengan 2016 mengalami peningkatan. Demikian hal nya dengan beban usaha yang mengalami penurunan pada tahun 2016.

Berdasarkan uraian di atas, maka penulis tertarik untuk mengadakan penelitian dengan judul "Analisis Rasio Keuangan Pada PT. Pegadaian (Persero) Cabang Ulak Karang". Dalam hal ini rasio yang akan dibahas adalah rasio likuiditas, solvabilitas, dan profitabilitas.

Sesuai dengan latar belakang masalah, penulis membuat perumusan sebagai berikut: Bagaimana Analisis Rasio Keuangan pada PT. Pegadaian (Persero) Cabang Ulak Karang berdasarkan tingkat Likuiditas, Solvabilitas, dan Profitabilitas dari tahun 2014 sampai tahun 2016.

\section{TINJAUAN PUSTAKA}

\section{Laporan Keuangan}

Hasil akhir dari pencatatan akuntansi adalah laporan keuangan dimana menurut Hill (2005:3) Laporan Keuangan itu adalah laporan yang menunjukkan posisi keuangan suatu saat tertentu, laporan perubahan atas perubahan posisi keuangan dari waktu ke waktu serta laporan atas hasil usaha perusahaan pada periode tertentu.

\section{Tujuan Laporan Keuangan}

Berdasarkan PSAK No. 1 revisi 2009 menyatakan tujuan laporan keuangan adalah memberikan informasi mengenai posisi keuangan, kinerja keuangan, dan arus kas entitas yang bermanfaat bagi sebagian besar kalangan pengguna laporan dalam pembuatan keputusan ekonomi.

\section{Analisis Rasio Keuangan}

Menurut Munawir (2007:64) "Rasio adalah menggambarkan suatu hubungan atau pertimbangan antara suatu jumlah tertentu dengan jumlah yang lain, dan dengan menggunakan alat analisis bahwa rasio yang dapat menjelaskan atau member gambaran kepada penganalisis tentang baik atau buruknya keadaan rasio dibandingkan dengan angka rasio perbandingan yang digunakan sebagai standar rasio keuangan".

\section{Jenis - Jenis Rasio Keuangan}

Menurut Kasmir (2012:127) Analisis Rasio terdiri dari :

\section{a. Ratio Likuiditas}

Rasio Likuiditas adalah rasio yang digunakan untuk mengukur kemampuan perusahaan dalam memenuhi kewajiban jangka pendeknya dengan aktiva lancar yang dimiliki. Rasio-rasio yang digunakan untuk mmenghitung ratio likuiditas adalah :

\section{a) Current Ratio}

Current Ratio atau Rasio Lancar merupakan alat ukur likuiditas yang diperoleh dengan membagi aktiva lancar dengan hutang lancar.

Adapun rumus current ratio ini adalah sebagai berikut :

$$
\text { Current Ratio }=\frac{\text { Aktiva Lancar }}{\text { Hutang Lancar }} \times 100 \%
$$




\section{b) Quick Ratio}

Quick Ratio adalah membandingkan antara aktiva lancar dikurangi persediaan dengan kewajiban lancar. Quick Ratio dihitung dengan rumus :

\section{c) Cash Ratio}

$$
\text { Quick Ratio }=\frac{\text { A. } \mathrm{L}-\text { Persediaan }}{\text { Hutang Lancar }} \times 100 \%
$$

Cash Ratio adalah rasio yang mengukur kemampuan perusahaan untuk membayar hutang lancarnya dengan kas yang tersedia dalam perusahaan. Cash Ratio dihitung dengan rumus :

\section{b. Ratio Solvabilitas}

$$
\text { Cash Ratio }=\frac{\text { Kas }}{\text { Hutang Lancar }} \times 100 \%
$$

Menurut Kasmir (2012:152) rasio solvabilitas ini merupakan rasio yang menggambarkan kemampuan perusahaan dalam membayar hutang jangka panjangnya.

Rasio yang digunakan adalah :

a) Total Debt to Asset Ratio (TDAR)

Rasio ini digunakan untuk mengukur kemampuan perusahaan dalam menjamin hutang-hutangnya dengan sejumlah aktiva yang dimiliki. Adapun rumus dari Total Debt to Asset Ratio adalah :

$$
T D A R=\frac{\text { Total Hutang }}{\text { Total Aktiva }} \times 100 \%
$$

b) Total Debt to Equity Ratio (Rasio Hutang Terhadap Modal)

Rasio ini mengukur seberapa jauh perusahaan dibelanjai oleh kreditur dan mengukur kemampuan perusahaan dalam melunasi kewajiban jangka panjangnya yang dihitung dengan melihat ekuitas dari perusahaan tersebut.

\section{c. Ratio Aktivitas}

$$
T D E R=\frac{\text { Total Hutang }}{\text { Modal Sendiri }} \times 100 \%
$$

Rasio ini merupakan rasio yang digunakan untuk mengukur efektivitas perusahaan dalam menggunakan aktiva yang dimilikinya atau dapat pula dikatakan rasio ini digunakan untuk mengukur tingkat efisiensi (efektivitas) pemanfaatan sumber daya perusahaan (Kasmir, 2012:172).

Rasio aktivitas ini terdiri dari :

a) Total Asset Turn Over Ratio

Rasio ini menunjukkan perputaran total aktiva diukur dari volume penjualan atau kemampuan semua aktiva menciptakan penjualan.

b) Total Receivable Turn Over

$$
\text { TATO }=\frac{\text { Penjualan Bersih }}{\text { Total Aktiva }} \times 1 \text { kali }
$$

Rasio ini menunjukkan berapa cepat penagihan piutang. 


\section{d. Ratio Profitabilitas}

$$
\text { Receivable Turn Over }=\frac{\text { Penjualan }}{\text { Piutang }} \times 1 \text { kali }
$$

Rasio Profitabilitas merupakan rasio yang digunakan dalam penilaian kinerja keuangan dalam menghasilkan laba dalam periode tertentu dan bertujuan untuk mengukur tingkat efektifitas manajemen dalam menjalankan operasional perusahaannya.

a) Net Profit Margin

Rasio ini menunjukkan keuntungan netto per penjualan.

$$
\begin{aligned}
& \text { Net Profit Margin } \\
& =\frac{\text { EAT }}{\text { Penjualan }} \times 100 \%
\end{aligned}
$$

b) Rate of Return On Investment (ROI)

Rasio ini menunjukkan kemampuan dari modal yang diinvestasikan dalam keseluruhan aktiva untuk menghasilkan keuntungan netto.

$$
R O I=\frac{\text { EAT }}{\text { Total Aktiva }} \times 100 \%
$$

c) Rate of Return On Equity (ROE)

Rasio ini menunjukkan kemampuan dari modal sendiri untuk menghasilkan keuntungan bagi pemegang saham prefern dan saham biasa.

$$
R O E=\frac{\text { EAT }}{\text { Modal Sendiri }} \times 100 \%
$$

\section{METODE PENELITIAN}

Dalam pengumpulan data dan bahan untuk melakukan penelitian ini, digunakan metode-metode pengumpulan data sebagai berikut :

\section{Metode Pengumpulan Data}

a. Studi Lapangan ( Field Research)

Penelitian ini dilakukan dengan menghubungi PT. Pegadaian (Persero) untuk memperoleh data yang diperlukan dan melakukan wawancara untuk mendapatkan data.

b. Studi Kepustakaan ( Library Research)

Penelitian ini dilakukan dengan cara mempelajari buku-buku bacaan laporan-laporan dan publikasi yang berhubungan dengan objek penelitian.

\section{Metode Analisa Data}

Dalam menganalisa data, menggunakan analisa data kualitatif dan kuantitatif. Dimana metode kualitatif yaitu memberikan gambaran dan analisis terhadap masalah yang diteliti, sedangkan metode kuantitatif yaitu melakukan perhitungan menggunakan rasio keuangan yaitu rasio likuiditas, rasio solvabilitas, dan rasio profitabilitas. 


\section{HASIL DAN PEMBAHASAN}

\section{Analisis Rasio Likuiditas pada PT. Pegadaian (Persero) Cabang Ulak Karang}

a. Current Ratio

Tahun 2014

Current Ratio

$$
\begin{aligned}
& =\frac{13.342 .211 .641}{293.940 .217} \times 100 \% \\
& =4.539,10 \%
\end{aligned}
$$

Current Ratio untuk tahun 2014 adalah 4.539,10\%, ini berarti setiap Rp 1 hutang lancar dapat dijamin dengan Rp 45,391 aktiva lancar yang dimiliki perusahaan. Tingkat current ratio yang terlalu besar mengakibatkan adanya aktiva lancar yang berlebihan sebaiknya perusahaan menggunakan asset yang dimiliki dalam bentuk investasi yang lain untuk meningkatkan laba perusahaan.

\section{Tahun 2015}

Current Ratio

$$
\begin{gathered}
=\frac{14.071 .755 .266}{149.661 .314} \times 100 \% \\
=9.402,40 \%
\end{gathered}
$$

Current Ratio untuk tahun 2015 adalah 9.402,40\%, ini berarti setiap Rp 1 hutang lancar dapat dijamin dengan Rp 94,024 aktiva lancar yang dimiliki perusahaan. Tingkat current ratio yang terlalu besar mengakibatkan adanya aktiva lancar yang berlebihan sebaiknya perusahaan menggunakan asset yang dimiliki dalam bentuk investasi yang lain untuk meningkatkan laba perusahaan.

\section{Tahun 2016}

\section{Current Ratio}

$$
=4.822,78 \%
$$

$$
=\frac{15.990 .493 .516}{331.561 .684} \times 100 \%
$$

Current Ratio untuk tahun 2016 adalah 4.822,78\%, ini berarti setiap Rp 1 hutang lancar dapat dijamin dengan Rp 48,2278 aktiva lancar yang dimiliki perusahaan. Tingkat current ratio yang terlalu besar mengakibatkan adanya aktiva lancar yang berlebihan sebaiknya perusahaan menggunakan asset yang dimiliki dalam bentuk investasi yang lain untuk meningkatkan laba perusahaan.

Dari perhitungan diatas bisa kita lihat bahwa besarnya rasio lancar selama 3 tahun terakhir mengalami fluktuasi, dimana pada tahun 2014 diperoleh rasio lancar sebesar $4.539,10 \%$ dan mengalami kenaikan pada tahun 2015 sebesar 4.863,30\% sehingga besarnya rasio lancar menjadi 9.402,40\%. Pada tahun 2016 rasio lancar perusahaan mengalami penurunan dari tahun sebelumnya sebesar 4.579,62\% sehingga menjadi $4.822,78 \%$. Jika dilihat dari rasio rata-rata industri 
perusahaan tergolong sehat, karena rasio lancar perusahaan berada di atas rata-rata industri sebesar $125 \%$.

b. Cash Ratio

\section{Tahun 2014}

Cash Ratio

$$
\begin{aligned}
& =\frac{211.651 .800}{293.940 .217} \times 100 \% \\
& =72,00 \%
\end{aligned}
$$

Pada tahun 2014 diperoleh cash ratio sebesar 72,00\%, ini berarti bahwa setiap Rp 1 hutang lancar dapat dijamin dengan kas dan bank sebesar Rp 0,72.

Tahun 2015

Cash Ratio

$$
\begin{aligned}
& =\frac{41.360 .200}{149.661 .314} \times 100 \% \\
& =27,63 \%
\end{aligned}
$$

Pada tahun 2015 diperoleh cash ratio sebesar 27,63\%, ini berarti bahwa setiap Rp 1 hutang lancar dapat dijamin dengan kas dan bank sebesar Rp 0,2763.

Tahun 2016

Cash Ratio

$$
=\frac{166.230 .500}{331.561 .684} \times 100 \%
$$

$=50,13 \%$

Pada tahun 2016 diperoleh cash ratio sebesar 50,13\%, ini berarti bahwa setiap Rp 1 hutang lancar dapat dijamin dengan kas dan bank sebesar Rp 0,5013.

Dari hasil analisis cash ratio diatas dapat diketahui bahwa laporan keuangan PT. Pegadaian (Persero) Cabang Ulak Karang pada tahun 2014 sebesar 72,00\%. Pada tahun 2015 terjadi penurunan, hal ini terjadi karena kas yang dimiliki oleh perusahaan berkurang sedangkan hutang lancar yang dimiliki mengalami sedikit pengurangan yaitu sebesar 44,37\%. Dan pada tahun 2016 cash ratio perusahaan kembali meningkat yaitu sebesar 22,50\% dari tahun sebelumnya. Jika dilihat dari rasio rata-rata industri, perusahaan tergolong sehat karena rasio kas perusahaan berada di atas rasio ratarata industri yaitu 35\%. Hanya saja pada tahun 2015 perusahaan memiliki cash ratio kurang dari $35 \%$ yaitu sebesar $27,63 \%$. 
2. Analisis Rasio Solvabilitas pada PT. Pegadaian (Persero) Cabang Ulak Karang

a. Total Debt to Total Asset Ratio (TDAR)

Tahun 2014

$T D A R$

$=\frac{317.168 .344}{14.328 .149 .489} \times 100 \%=2,21 \%$

Rasio hutang yang diperoleh perusahaan pada tahun 2014 adalah sebesar 2.21\%. Yang berarti bahwa setiap Rp 1 aktiva dapat membiayai total hutang sebesar Rp 0,0221.

\section{Tahun 2015}

$T D A R$

$=\frac{190.997 .202}{15.148 .374 .097} \times 100 \%=1,26 \%$

Rasio hutang yang diperoleh perusahaan pada tahun 2015 adalah sebesar 1,26\%. Yang berarti bahwa setiap Rp 1 aktiva dapat membiayai total hutang sebesar Rp 0,0126.

Tahun 2016

$T D A R$

$=\frac{331.561 .684}{17.653 .807 .692} \times 100 \%=1,88 \%$

Rasio hutang yang diperoleh perusahaan pada tahun 2016 adalah sebesar $1,88 \%$. Yang berarti bahwa setiap Rp 1 aktiva dapat membiayai total hutang sebesar Rp 0,0188.

Dari perhitungan diatas dapat dilihat bahwa pada tahun 2014, Total Debt to Total Asset Ratio menunjukkan nilai sebesar 2,21\%. Pada tahun 2015 Debt to Total Asset Ratio perusahaan mengalami penurunan sebesar 0,95\% dari tahun sebelumnya. Dan pada tahun 2016 Debt to Total Asset Ratio mengalami kenaikan sebesar 0,62\% sehingga Debt to Total Asset Ratio PT. Pegadaian (Persero) Cabang Ulak Karang tahun 2016 menjadi 1,88\%.

3. Analisis Rasio Profitabilitas pada PT. Pegadaian (Persero) Cabang Ulak Karang

a. Gross Profit Margin (Margin Laba Kotor

\section{Tahun 2014}

$$
\begin{aligned}
& G P M=\frac{2.648 .492 .739}{2.648 .492 .739} \times \quad 100 \% \\
& =100 \%
\end{aligned}
$$

Dari Rp 1 penjualan akan menghasilkan laba kotor sebesar Rp 1 . Semakin besar Gross Profit Margin maka akan semakin baik keadaan perusahaan.

Tahun 2015

$$
\begin{array}{rlr}
G P M & =\frac{3.445 .645 .710}{3.420 .167 .918} \times & 100 \% \\
& =100,74 \% &
\end{array}
$$

Dari Rp 1 penjualan akan menghasilkan laba kotor sebesar Rp 1,0074. Semakin besar Gross Profit Margin maka akan semakin baik keadaan perusahaan. 
Tahun 2016

$$
G P M=\frac{4.511 .327 .612}{3.434 .318 .246} \times \quad=131,36 \%
$$

Dari Rp 1 penjualan akan menghasilkan laba kotor sebesar Rp 1,3136. Semakin besar Gross Profit Margin maka akan semakin baik keadaan perusahaan.

Berdasarkan perhitungan diatas dapat dilihat bahwa rasio laba kotor PT. Pegadaian (Persero) Cabang Ulak Karang mengalami kondisi yang berfluktuasi, dimana pada tahun 2014 perusahaan memiliki laba kotor sebesar 100\% sedangkan pada tahun 2015 naik sebesar $0,74 \%$ sehingga laba kotor perusahaan menjadi $100,74 \%$. Pada tahun 2016 laba kotor perusahaan meningkat sebesar 30,62\% sehingga laba kotor perusahaan menjadi $131,36 \%$.

b. Net Profit Margin (Margin Laba Bersih)

Tahun 2014

$$
\begin{gathered}
\text { Net Profit Margin }=\frac{1.087 .888 .001}{2.648 .492 .739} \times 100 \% \\
=41,07 \%
\end{gathered}
$$

Dari setiap Rp 1 penjualan akan menghasilkan laba bersih sebesar Rp 0,41 .

\section{Tahun 2015}

$$
\begin{gathered}
\text { Net Profit Margin }=\frac{725.941 .849}{3.420 .167 .918} \times 100 \% \\
=21,22 \%
\end{gathered}
$$

Dari setiap Rp 1 penjualan akan menghasilkan laba bersih sebesar Rp 0,21 .

\section{Tahun 2016}

Net Profit Margin

$$
\begin{array}{r}
=\frac{1.297 .433 .751}{3.434 .318 .246} \times 100 \% \\
=37,78 \%
\end{array}
$$

Dari setiap Rp 1 penjualan akan menghasilkan laba bersih sebesar Rp 0,37 .

Berdasarkan perhitungan di atas dapat dilihat laba bersih perusahaan mengalami kondisi yang berfluktuasi. Pada tahun 2014 laba bersih perusahaan sebesar $41,07 \%$ dan pada tahun 2015 mengalami penurunan sebesar 19,85\% sehingga menjadi 22,21\%. Dan pada tahun 2016 kembali mengalami peningkatan sebesar 16,56\% sehingga laba bersih yang dimiliki perusahaan menjadi $37,78 \%$. Ini disebabkan karena tingkat penjualan mengalami kenaikan dari tahun 2015-2016.

c. Return On Investment

\section{Tahun 2014}

$$
R O I=\frac{1 \cdot 087.888 .001}{14 \cdot 328.149 .489} \times 100 \%=7,60 \%
$$


Hasil pengembalian yang diperoleh PT. Pegadaian (Persero) Cabang Ulak Karang pada tahun 2014 adalah sebesar 7,60\%. Ini menunjukkan kemampuan perusahaan dalam menghasilkan laba bersih dari aktiva adalah sebesar $7,60 \%$

\section{Tahun 2015}

$$
R O I=\frac{725.941 .849}{15.148 .374 .097} \times 100 \%=4,80 \%
$$

Hasil pengembalian yang diperoleh PT. Pegadaian (Persero) Cabang Ulak Karang pada tahun 2015 adalah sebesar 4,80\%. Ini menunjukkan kemampuan perusahaan dalam menghasilkan laba bersih dari aktiva adalah sebesar $4,80 \%$.

\section{Tahun 2016}

$$
R O I=\frac{1.297 .433 .751}{17.653 .807 .692} \times 100 \%=7,35 \%
$$

Hasil pengembalian yang diperoleh PT. Pegadaian (Persero) Cabang Ulak Karang pada tahun 2016 adalah sebesar 7,35\%. Ini menunjukkan kemampuan perusahaan dalam menghasilkan laba bersih dari aktiva adalah sebesar $7,35 \%$.

Dari perhitungan diatas dapat dilihat bahwa ROI PT. Pegadaian (Persero) Cabang Ulak Karang mengalami kondisi yang naik turun. Pada tahun 2014 ROI perusahaan sebesar 7,60\%. Pada tahun 2015 ROI perusahaan menurun sebesar 2,80\% sehingga ROI perusahaan menjadi 4,80\%. Pada tahun 2016 ROI perusahaan meningkat sebesar $2,55 \%$ sehingga ROI perusahaan menjadi $7,35 \%$.

d. Return On Assets

\section{Tahun 2014}

$$
R O A=\frac{2.648 .492 .739}{14.328 .149 .489} \times 100 \%=18,48 \%
$$

Semakin besar Return On Assets yang diperoleh PT. Pegadaian (Persero) Cabang Ulak Karang maka akan semakin baik, yang berarti perusahaan semakin baik dalam mengelola asset untuk menghasilkan laba.

\section{Tahun 2015}

$$
R O A=\frac{3.445 .645 .710}{15.148 .374 .097} \times 100 \%=22,75 \%
$$

Semakin besar Return On Assets yang diperoleh PT. Pegadaian (Persero) Cabang Ulak Karang maka akan semakin baik, yang berarti perusahaan semakin baik dalam mengelola asset untuk menghasilkan laba.

\section{Tahun 2016}

$$
R O A=\frac{4.511 .327 .612}{17.653 .807 .692} \times 100 \%=25,55 \%
$$

Semakin besar Return On Assets yang diperoleh PT. Pegadaian (Persero) Cabang Ulak Karang maka akan semakin baik, yang berarti perusahaan semakin baik dalam mengelola asset untuk menghasilkan laba. 
Dari perhitungan diatas dapat dilihat bahwa ROA perusahaan meningkat. Pada tahun 2014 total ROA perusahaan sebesar 18,48\%. Pada tahun 2015 ROA perusahaan meningkat sebesar 4,27\% dari tahun sebelumnya, sehingga ROA perusahaan menjadi $22,75 \%$. Dan pada tahun 2016 ROA perusahaan meningkat sebesar 2,80\% sehingga ROA perusahaan menjadi $25,55 \%$. Dari perhitungan ROA dari tahun 2014 sampai 2016 rasio ROA tertinggi adalah 25,55\% pada tahun 2016, artinya tingkat pengembalian dari asset yang dimiliki perusahaan relatif baik.

\section{KESIMPULAN}

a. Dari segi likuiditasnya, perusahaan sudah mampu memenuhi kewajiban jangka pendeknya. Hal ini dibuktikan dengan nilai current ratio dan cash ratio berada diatas rasio rata-rata perusahaan. Dari segi current ratio pada tahun 2014 sampai dengan 2016 yaitu sebesar 4.539,10\%, 9.402,40\%, dan $4.822,78 \%$ dengan rasio rata-rata industri $200 \%$. Sedangkan pada segi cash ratio hanya pada tahun 2015 yang berada dibawah rasio ratarata perusahaan yaitu sebesar $27,63 \%$ dengan rasio rata-rata industri sebesar 35\%, selanjutnya pada tahun 2014 dan 2016 rasio perusahaan berada diatas rasio rata-rata industri yaitu $72,00 \%$ dan $50,13 \%$. Meskipun rasio likuiditas perusahaan sudah berada diatas rasio rata-rata industri, perusahaan seharusnya menjaga dan meningkatkan kemampuannya dalam mengelola hutang yang segera dapat dipenuhi.

b. Dari segi solvabilitasnya, perusahaan harus menjaga kinerja keuangan perusahaan agar tidak terjadi penurunan pada tahun-tahun selanjutnya yang juga bisa mengakibatkan perusahaan tidak likuid.

c. Dari segi profitabilitas, perusahaan lebih lagi meningkatkan kinerja keuangannya dalam menghasilkan laba atau pendapatan bagi perusahaan yang akan menunjang kegiatan operasional perusahaan. Dari GPM perusahaan dari tahun 2014 sampai dengan 2016 sebesar 100,00\%, $100,74 \%, 131,36 \%$. NPM perusahaan dari tahun 2014 sampai dengan 2016 sebesar 41,07\%, 21,22\%, 37,78\%. ROI perusahaan dari tahun 2014 sampai dengan 2016 sebesar 7,60\%, 4,80\%, 7,35\%. ROA perusahaan dari tahun 2014 sampai 2016 sebesar 18,48\%, 22,75\%, 25,55\%.

Jika dilihat hasil keseluruhan yang telah diteliti berdasarkan rasio likuiditas, solvabilitas, dan rasio profitabilitas perusahaan cenderung berfluktuasi dan ketidakstabilan atas kinerja perusahaan. Meskipun demikian PT. Pegadaian (Persero) Cabang Ulak karang termasuk kedalam kategori baik dan telah memenuhi standar rata-rata industri yang ditetapkan oleh Keputusan Menteri BUMN Nomor KEP-100/MBU/2002. 


\section{DAFTAR PUSTAKA}

Afriyeni, A. (2017). Profitabilitas Bank Perkreditan Rakyat Di Kota Padang Di Tinjau Dari Rasio Likuiditas. Jurnal Benefita: Ekonomi Pembangunan Manajemen Bisnis Dan Akuntansi. Volume 2. No. 1. http://doi.org/10.22216/jbe.v2i1.2104

Afriyeni, A. Fernos, J (2018). Analisis Faktor-Faktor Penentu Kinerja Profitabilitas Bank Perkreditan Rakyat (BPR) Konvensional Di Sumatera Barat. Jurnal Benefita: Ekonomi Pembangunan Manajemen Bisnis Dan Akuntansi. Volume 3. No. 3. http://doi.org/10.22216/jbe.v3i3.3623

Arifin, I. Z., \& Marlius, D. (2017). Analisis Kinerja Keuangan PT. Pegadaian Cabang Ulak Karang. https://doi.org/10.31227/osf.io/n2peu

Darminto, Dwi Prastowo. 2005. “Analisis Laporan Keuangan”. Yogyakarta : Andi.

Fernos, J (2017). Analisis Rasio Profitabilitas Untuk Mengukur Kinerja (Studi Kasus Pada PT. Bank Pembangunan Daerah Provinsi Sumatera Barat. Jurnal Pundi. Vol 01. No 02. https://doi.org/10.31575/jp.v1i2.25

Handayani, M., \& Marlius, D. (2017). Analisis Tingkat Kesehatan PT. BPR Batang Kapas. https://doi.org/10.31227/osf.io/bq48z

Harahap, Sofyan Syarif. 2009. “Analisis Kritis Atas Laporan Keuangan”. Jakarta : PT. Raja Grafindo Persada.

Hill, MC, Graw. 2005. “Analisis Laporan Keuangan”. Edisi 8. Jakarta : Salemba Empat.

http://www.pegadaian.co.id

Ikatan Akuntansi Indonesia. Revisi 2009. Jakarta : Salemba Empat.

Iswari, M., \& Fernos, J. (2019). Analisis Tingkat Kesehatan Bank Pada PT. Bank Pembangunan Daerah Sumatera Barat. https://doi.org/10.31227/osf.io/ja7ty

Kasmir. 2012. “Analisis Laporan Keuangan”. Jakarta : PT. Raja Grafindo Persada.

Keputusan Menteri BUMN Nomor KEP-100/MBU/2002 tentang standar rasio rata-rata industri pada PT. Pegadaian (Persero). 
Latif, F., \& Fernos, J. (2019). Analisis Rasio Profitabilitas Untuk Mengukur Kinerja Bank BPR Harau Payakumbuh. https://doi.org/10.31227/osf.io/27vqg

Munawir. 2007. “Analisis Laporan Keuangan”. Yogyakarta : Liberty.

Oktavia, L., \& Fernos, J. (2019). Analisis Laporan Keuangan Berdasarkan Tingkat Rentabilitas Bank Perkreditan Rakyat (BPR) Batang Palangki. https://doi.org/10.31227/osf.io/tbqdv

Putri, Y. A., \& Marlius, D. (2018). Analisis Tingkat Kesehatan Bank Pada PT. Bank Perkreditan Rakyat (BPR) Jorong Kampuang Tangah Pariaman Cabang Padang. https://doi.org/10.31227/osf.io/r98pv

Rahmayeli, D. S., \& Marlius, D. (2017). Analisis Kinerja Keuangan Pada PT. Bank Perkreditan Rakyat (BPR) Batang Kapas Pesisir Selatan. https://doi.org/10.31227/osf.io/sz5db

Suherti, E., \& Fernos, J. (2019). Analisa Rasio Terhadap Laporan Keuangan Pada PT. Bank Pembangunan Daerah Sumatera Barat. https://doi.org/10.31227/osf.io/9zte8

Syamsudin, Lukman. 2008. "Manajemen Keuangan Perusahaan (Konsep Aplikasi dalam Perencanaan Pengawasan dan Pengambilan Keputusan)”. Jakarta : PT. Grafindo Persada.

Walidaini, Ridhatul. 2011. "Analisis Laporan Keuangan Sebagai Alat Ukur Kinerja Keuangan Perusahaan (Studi Kasus Pada PT. Permodalan Nasional Madani) Persero". Skripsi Sekolah Tinggi Ilmu Keuangan, Perbankan dan Pembangunan Padang.

Zahara, Siti. 2012. "Analisa Kinerja Keuangan Pada PT. Bank Perkreditan Rakyat Pagaruyung Cabang Padang Panjang Dengan Menggunakan Rasio Keuangan". Tugas Akhir Akademi Keuangan Perbankan dan Pembangunan Padang. 